\title{
The Impact of Perception of Psychological Contract Compliance on Organizational Citizenship Behavior of SMEs Workers
}

\author{
*Wang-je Song, Dept. of Smart Convergence Consulting, Hansung University, Seoul, 02876, Korea, \\ wangje61@gmail.com \\ Yen-yoo You, Dept. of Smart Convergence Consulting, Hansung University, Seoul, 02876, Korea \\ ${ }^{*}$ Corresponding author
}

\begin{abstract}
Background/Objectives: Small and medium-sized enterprises(SMEs) lack resources compared to large enterprises, so their explicit wage level and welfare benefits are relatively weak. Therefore, by recognizing compliance with psychological contracts, it was decided to check whether it could induce OCB that affects organizational performance.

Methods/Statistical analysis: The research model and hypothesis were established based on the existing studies. Whether or not to comply with psychological contracts recognized by workers in SMEs was an independent variable, and their OCB was set as a dependent variable. Organizational loyalty was set as a parameter between the two variables while confirming the mutual influence. Data was collected through a questionnaire. Data analysis was performed using SPSS 23.0 and AMOS 22.0 programs.

Findings: According to the outcome of this study, Perceptions of compliance with psychological contracts do not directly affect OCB. It was confirmed that the perception of compliance with psychological contracts affect the organizational loyalty, and organizational loyalty exert influence on OCB. Therefore, it was confirmed that the perception of compliance with psychological contracts indirectly influences OCB through organizational loyalty. Among psychological contracts, in the comparison between the transactional psychological contract and the relational psychological contract, it was confirmed that the transactional psychological contract had a greater influence on organizational loyalty.

Improvements/Applications: In order to induce OCB of SMEs workers, it is necessary to pay attention to organizational loyalty. To this end, it is necessary to manage psychological contracts, especially transactional psychological contracts.
\end{abstract}

Keywords: Psychological contract, OCB, Organizational loyalty, SMEs, Consulting Received: 14.12.2020 $\quad$ Accepted: 08.01.2021 $\quad$ Published: 03.02.2021

\section{INTRODUCTION}

With the development of information technology, all changes in the world are accelerating. therefore all industrial environments are rapidly changing. Therefore, companies are concerned that organizational structure and employment patterns will change. These concerns also affect traditional psychological contracts between the organization and its members. Also, due to the globalization of manpower, the possibility of moving members is increasing[1]. The problem of SMEs starts with the problem of corporate governance that always exists after the existence of a corporate organization. Furthermore, the content differs from that of large companies due to economic problems [2].

In this study, the influence of workers' perception that a company is complying with psychological contracts on workers' OCB will be confirmed, and the contents of previous studies on the mediating effect of organizational loyalty will be reviewed. By specializing and testing this for SMEs, the purpose of this study is to present a theoretical basis for SMEs management or HR consultants to review and reflect on organizational operation.

In general, it is the content and condition of the consciously and unconsciously interacting exchange that exists between the manager and the organizational member in an employment relationship other than an explicit contract, and an undocumented expectation is called a psychological contract[3].

Therefore, the expectations of the members of the organization about what they should be provided by the organization and what they should provide to the organization, and the expectations of the organization about what the organization should provide to the organization members and what the organization should provide to the organization members. The degree can be regarded as important[4].

Types of psychological contracts are classified into transactional contracts and relational contracts based on the study of Rousseau by most scholars[5], and it is said that psychological contract violations affect the members' organizational loyalty. It was said that the influence of relational contracts 
is greater than that of enemy contracts.

OCB can be represented by actions outside the role of workers, and is well known for effectively increasing organizational performance[6]. Organized civic behavior is not related to the organizational compensation system for official workers, nor is it defined as an action within the official role. However, it can be defined as the job-related behavior of workers that promote the effective functioning of the organization[7].

OCB is a member's personal and voluntary contribution to the organization other than the officially required role of the members, and refers to a voluntary action that promotes the effective functioning of the organization[8]. Since organizational performance is revealed through the actions of members of the organization, it is very important for members of the organization to fulfill their roles faithfully.

However, since it is virtually impossible to formalize all roles that members have to perform, not only faithfully fulfilling the prescribed roles, but also voluntary and voluntary contributions of members of the organization can be said to be essential to improving organizational performance[9].

Existing studies related to psychological contracts and OCB show that under psychological contract violations, members are affected by negative factors such as turnover intention and negligence $[10,11,12]$. It was found to have a positive $(+)$ relationship and a negative $(-)$ relationship with organizational.

\section{Materials and Methods}

\subsection{Collecting data}

This study targeted workers who are currently employed in SMEs located in Korea, defined as 500 or fewer workers. A survey was conducted on whether workers perceived compliance with psychological contracts, their organizational loyalty, and OCB, and a Likert scale was used in the questionnaire. The scale was composed of a 5-point scale.

A total of 273 questionnaires were collected, but among the collected questionnaire responses, employees in large corporations (more than 500) and 55 questionnaire responses with unscrupulous answers were excluded.

\subsection{Research model}

This study was designed based on existing studies. The effect of the perception of psychological contract compliance on workers' OCB was confirmed. And it tried to analyze the mediating effect of organizational loyalty. In addition, we tried to compare the magnitude of the effect of transactional psychological contracts and relationship psychological contracts on loyalty. Figure 1 shows the research model of this contrivance.

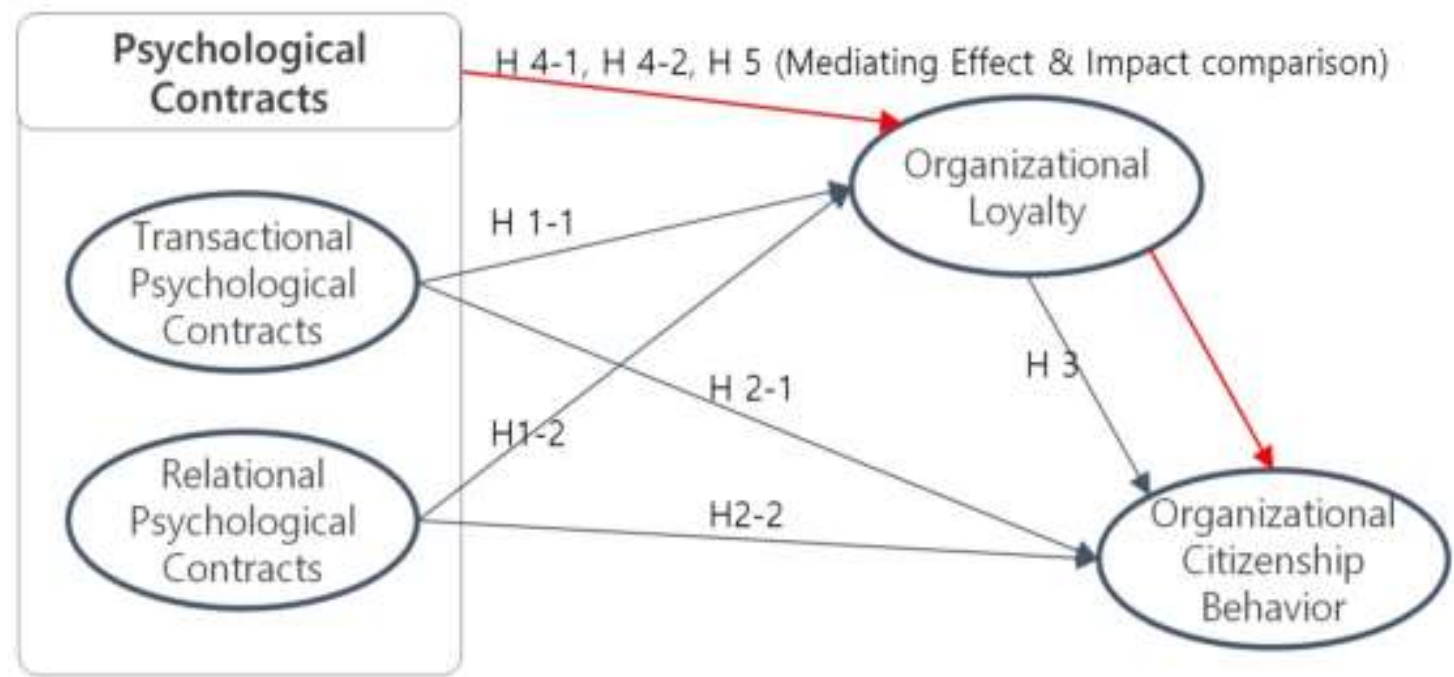

Figure 1 Research model 


\subsection{Research Hypothesis}

The counter-hypothesis is as follows on the relationship between the perception of psychological contract compliance, $\mathrm{OCB}$, and organizational loyalty.

H1. Compliance with psychological contracts will have a positive effect on organizational loyalty.

H1-1 Compliance with transactional psychological contracts will have a positive effect on organizational loyalty.

H 1-2 Compliance with relational psychological contracts will have a positive effect on organizational loyalty.

H2. Compliance with psychological contracts will have a positive effect on OCB.

H 2-1 Compliance with transactional psychological contracts will have a positive effect on OCB.

H 2-2 Compliance with relational psychological contracts will have a positive effect on OCB.

H3. Organizational loyalty will have a positive effect on OCB.

H4. Organizational loyalty will mediate the impact of psychological contracts compliance on OCB.

H 4-1 Organizational loyalty will mediate the relationship between perceptions of compliance with a transactional psychological contracts and OCB.

$\mathrm{H}$ 4-2 Organizational loyalty will mediate the relationship between awareness of relational psychological contracts compliance and OCB

H 5. Compliance with relational psychological contracts will have a greater impact on organizational loyalty than compliance with transactional psychological contracts.

\subsection{Operational Definition of Variables}

Based on the previous research, this study divided questionnaire by dividing the customer satisfaction competency of consultant into consultant communication skills and Consultant job competency. The operational definition of the measurement variable and the composition of the questionnaire are summarized as shown in Table 1.

Table 1 Questionnaire

\begin{tabular}{|c|c|c|c|c|}
\hline \multicolumn{2}{|c|}{ Evaluation items } & \multirow{2}{*}{\begin{tabular}{|l} 
Operational definition \\
- fair promotion opportunity \\
· fair evaluation system \\
- pleasant working environment \\
- appropriate level of salary \\
- appropriate compensation
\end{tabular}} & \multirow{2}{*}{\begin{tabular}{|l} 
source \\
Robinson \\
Rousseau(1994)[13]
\end{tabular}} & \multirow{2}{*}{$\begin{array}{l}\text { questions } \\
5\end{array}$} \\
\hline \multirow{2}{*}{$\begin{array}{l}\text { Compliance } \\
\text { with } \\
\text { psychological } \\
\text { contracts }\end{array}$} & $\begin{array}{l}\text { Transactional } \\
\text { P. C. }\end{array}$ & & & \\
\hline & $\begin{array}{l}\text { Relational } \\
\text { P. C. }\end{array}$ & $\begin{array}{l}\text { - education and training opportunities } \\
\text { - employment security } \\
\text { - career development opportunities } \\
\text { - private support }\end{array}$ & $\begin{array}{l}\text { Turnley \& } \\
\text { Feldman(1998)[14] }\end{array}$ & 4 \\
\hline $\begin{array}{l}\text { Organizational } \\
\text { behavior }\end{array}$ & citizenship & $\begin{array}{l}\text { - sincere job performance } \\
\text { - compliance with company rules } \\
\text { - efforts to meet company requirements } \\
\text { - familiarity with announcements } \\
\text { - self-development }\end{array}$ & $\begin{array}{l}\text { Organ(1988)[7] } \\
\text { Podsakoff(2009)[9] }\end{array}$ & 8 \\
\hline
\end{tabular}




\begin{tabular}{l|l|l|}
\cline { 2 - 3 } Organizational loyalty & $\begin{array}{l}\text { - willingness to work continuously } \\
\text { - recommending acquaintances } \\
\text { - promoting the company } \\
\text { - trusting the company's products } \\
\text { - empathizing with the company's values } \\
\text { - friendship }\end{array}$ & Mahal(2012)[15] \\
Kumar & Shkhar(2012)[16]
\end{tabular}

\section{Results and Discussion}

\subsection{Statistical analysis results}

\subsubsection{Technical statistics analysis}

In the analysis of descriptive statistics for the measured variable, the standard deviation was 1.286, which satisfies the condition of 3 or less, and the skewness and kurtosis satisfied the condition of the absolute value of .767 and .925 , respectively.

\subsubsection{Exploratory factor analysis \& reliability analysis}

In order to be considered suitable in exploratory factor analysis 'commonness' should be 0.4 or higher. In addition, the factor loading should be 0.6 or more, and Bartlett's sphericity test should have a P value of 0.05 or less. If the criteria were not met, the item was deleted and measured again. Finally, the rest of the items met all conditions.

Reliability analysis was adopted when the 'Cronbach $\alpha$ 'value was 0.6 or higher.

Higher reliability was secured by removing three items (T-PC 1 \& 2 \& 3) among the transactional psychological contract variables and one item (OL 8) among the organizational loyalty variables.

The analysis results after removing the inappropriate variable are shown in Tables 2 to 4 .

Table 2 Exploratory factor analysis \& reliability analysis - psychological contract

\begin{tabular}{|c|c|c|c|c|c|c|c|c|c|}
\hline \multirow{2}{*}{\multicolumn{2}{|c|}{ latent variable }} & \multirow{2}{*}{$\begin{array}{l}\text { Measureme } \\
\text { nt item }\end{array}$} & \multicolumn{2}{|c|}{ factor loading } & \multirow{2}{*}{$\begin{array}{l}\text { Commu- } \\
\text { nality }\end{array}$} & \multirow{2}{*}{$\begin{array}{l}\text { Eigen } \\
\text { value }\end{array}$} & \multirow{2}{*}{ variance } & \multirow{2}{*}{$\begin{array}{l}\text { Cronbach } \alpha \text { if } \\
\text { item deleted }\end{array}$} & \multirow{2}{*}{ Cronbach $\alpha$} \\
\hline & & & 1 & 2 & & & & & \\
\hline \multirow{6}{*}{$\begin{array}{l}\text { Compliance } \\
\text { with } \\
\text { psychological } \\
\text { contracts }\end{array}$} & \multirow{4}{*}{$\begin{array}{l}\text { Transactional } \\
\text { psychological } \\
\text { contracts }\end{array}$} & R-PC 3 & .813 & 345 & .864 & \multirow{4}{*}{2.511} & \multirow{4}{*}{41.847} & .748 & \multirow{4}{*}{.814} \\
\hline & & R-PC 2 & .794 & 070 & .799 & & & .795 & \\
\hline & & R-PC 1 & .737 & 360 & .673 & & & .705 & \\
\hline & & R-PC 4 & .697 & 222 & .635 & & & 809 & \\
\hline & \multirow{2}{*}{$\begin{array}{l}\text { Relational } \\
\text { psychological contracts }\end{array}$} & T-PC 4 & .134 & 920 & .780 & \multirow{2}{*}{1.776} & \multirow{2}{*}{29.592} & & \multirow{2}{*}{-782} \\
\hline & & T-PC 5 & .416 & 791 & .535 & & & & \\
\hline
\end{tabular}

Table 3 Exploratory factor analysis \& reliability analysis - Organizational Citizenship Behavior

\begin{tabular}{|c|c|c|c|c|c|c|c|}
\hline latent variable & $\begin{array}{l}\text { Measurement } \\
\text { item }\end{array}$ & factor loading & communalit & eigen value & variance & $\begin{array}{l}\text { Cronbach } \alpha \text { if } \\
\text { item deleted }\end{array}$ & Cronbach $\alpha$ \\
\hline \multirow{8}{*}{$\begin{array}{l}\text { Organizational } \\
\text { Citizenship } \\
\text { Behavior }\end{array}$} & OCB 5 & 804 & 647 & \multirow{8}{*}{4.279} & \multirow{8}{*}{53.492} & 846 & \multirow{8}{*}{873} \\
\hline & OCB 3 & 778 & 605 & & & 853 & \\
\hline & OCB 4 & 767 & 588 & & & 853 & \\
\hline & OСВ 2 & 742 & 551 & & & 855 & \\
\hline & OCB 6 & 736 & 541 & & & 857 & \\
\hline & OCB 1 & 716 & 512 & & & 859 & \\
\hline & OCB 7 & 658 & 434 & & & 864 & \\
\hline & OCB 8 & 633 & 401 & & & 869 & \\
\hline
\end{tabular}


Table 4 Exploratory factor analysis \& reliability analysis - Organizational loyalty

\begin{tabular}{|c|c|c|c|c|c|c|c|}
\hline latent variable & $\begin{array}{l}\text { Measurement } \\
\text { item }\end{array}$ & factor loading & communalit & eigen value & variance & $\begin{array}{l}\text { Cronbach } \alpha \\
\text { item deleted }\end{array}$ & if Cronbach $\alpha$ \\
\hline \multirow{7}{*}{$\begin{array}{l}\text { Organizational } \\
\text { loyalty }\end{array}$} & OL 2 & 900 & 810 & \multirow{7}{*}{5.028} & \multirow{7}{*}{71.827} & 917 & \multirow{7}{*}{.934} \\
\hline & OL 1 & 888 & 788 & & & 919 & \\
\hline & OL 4 & 884 & 781 & & & 919 & \\
\hline & OL 3 & 840 & 706 & & & 925 & \\
\hline & OL 5 & 809 & 655 & & & 928 & \\
\hline & OL 6 & 814 & 662 & & & 927 & \\
\hline & OL 7 & 791 & 625 & & & 930 & \\
\hline
\end{tabular}

\subsubsection{Confirmatory factor analysis}

Through analysis with SPSS 23.0, items that were judged to be inappropriate were removed, and confirmatory factor analysis using AMOS 22.0 was performed with only the remaining items.

The measurement model for confirmatory factor analysis is shown in Figure 2.

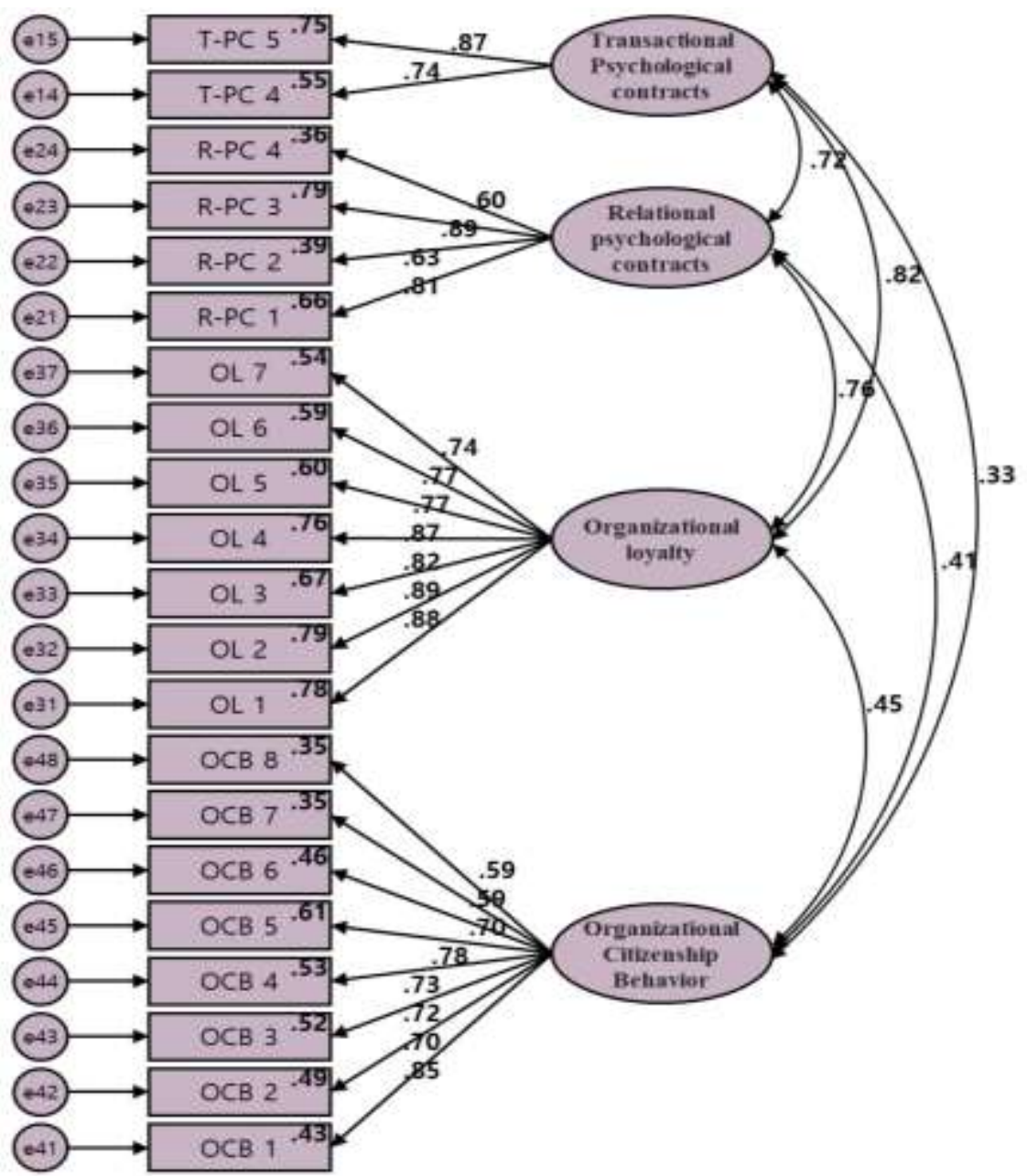

Figure 2 Confirmatory factor analysis

In the confirmatory factor analysis, a total of 4 items, such as R-PC 2 and 4, and OCB 7 and 8, whose SMC values were less than 0.4 were additionally deleted. Table 5 shows the confirmatory factor analysis results that were verified again after deleting the nonconforming item. 
Table 5 Confirmatory factor analysis

\begin{tabular}{|c|c|c|c|c|c|c|c|c|c|c|}
\hline Latent variable & $\begin{array}{l}\text { Measurem } \\
\text { ent item }\end{array}$ & $\begin{array}{l}\text { Standardized } \\
\text { factor } \\
\text { loading }\end{array}$ & $\begin{array}{l}\text { Unstandardize } \\
\text { d factor } \\
\text { loading }\end{array}$ & S.E & C.R. & $P$ & AVE & $\mathrm{CR}$ & SMC & $\begin{array}{l}\text { Cronb } \\
\text {-ach } \alpha\end{array}$ \\
\hline \multirow{2}{*}{$\begin{array}{l}\text { Transactional } \\
\text { psychological } \\
\text { contracts }\end{array}$} & T-PC 4 & .743 & 1 & & & & \multirow[b]{2}{*}{.625} & \multirow[b]{2}{*}{.768} & .551 & \multirow[b]{2}{*}{.856} \\
\hline & T-PC 5 & .867 & 1.25 & .111 & $\begin{array}{l}11.28 \\
2\end{array}$ & $* * *$ & & & .752 & \\
\hline \multirow{2}{*}{$\begin{array}{l}\text { Relational } \\
\text { psychological } \\
\text { contracts }\end{array}$} & R-PC 1 & .826 & 1 & & & & \multirow[b]{2}{*}{.677} & \multirow[b]{2}{*}{.807} & .683 & \multirow[b]{2}{*}{.782} \\
\hline & R-PC 3 & .915 & 0.955 & .067 & $\begin{array}{l}14.23 \\
2\end{array}$ & $* * *$ & & & .837 & \\
\hline \multirow{7}{*}{ Organizational loyalty } & OL 1 & .884 & 1 & & & & \multirow{7}{*}{.623} & \multirow{7}{*}{.920} & .781 & \multirow{7}{*}{.934} \\
\hline & OL 2 & .892 & 1.104 & .058 & $\begin{array}{l}19.12 \\
7\end{array}$ & $* * *$ & & & .796 & \\
\hline & OL 3 & .817 & 1.072 & .067 & $\begin{array}{l}16.08 \\
4\end{array}$ & $* * *$ & & & .667 & \\
\hline & OL 4 & .867 & 1.05 & .058 & $\begin{array}{l}18.09 \\
8\end{array}$ & $* * *$ & & & .752 & \\
\hline & OL 5 & .772 & 0.943 & .065 & $\begin{array}{l}14.55 \\
5\end{array}$ & $* * *$ & & & .596 & \\
\hline & OL 6 & .766 & 0.876 & .061 & 14.37 & $* * *$ & & & .587 & \\
\hline & OL 7 & .734 & 0.796 & .059 & $\begin{array}{l}13.40 \\
4\end{array}$ & $* * *$ & & & .539 & \\
\hline \multirow{6}{*}{$\begin{array}{l}\text { Organizational } \\
\text { Citizenship Behavior }\end{array}$} & OCB 1 & .672 & 1 & & & & \multirow{6}{*}{.661} & \multirow{6}{*}{.921} & .452 & \multirow{6}{*}{.865} \\
\hline & OCB 2 & .696 & 1.215 & .137 & 8.846 & $* * *$ & & & .485 & \\
\hline & OCB 3 & .758 & 1.074 & .118 & 9.104 & $* * *$ & & & .574 & \\
\hline & OCB 4 & .743 & 1.15 & .125 & 9.169 & $* * *$ & & & .552 & \\
\hline & OCB 5 & .749 & 1.343 & .139 & 9.679 & $* * *$ & & & .561 & \\
\hline & OCB 6 & .706 & 1.153 & .131 & 8.821 & $* * *$ & & & .498 & \\
\hline model fit & \multicolumn{10}{|c|}{$\begin{array}{l}\mathrm{CMIN}=296.433, \mathrm{df}=113, \mathrm{p}=.000, \mathrm{CMIN} / \mathrm{DF}=2.623 \\
\mathrm{RMR}=.056, \mathrm{GFI}=.860, \mathrm{AGFI}=.811 \\
\mathrm{IFI}=926 . \mathrm{TLI}=910, \mathrm{CFI}=.925 . \mathrm{RMSEA}=.086\end{array}$} \\
\hline
\end{tabular}

\subsection{Hypothesis verification}

\subsubsection{Structural Equation Modeling}

The hypothesis was verified using the structural equation model of AMOS 22.0, and the contents are shown in Figure 3. 


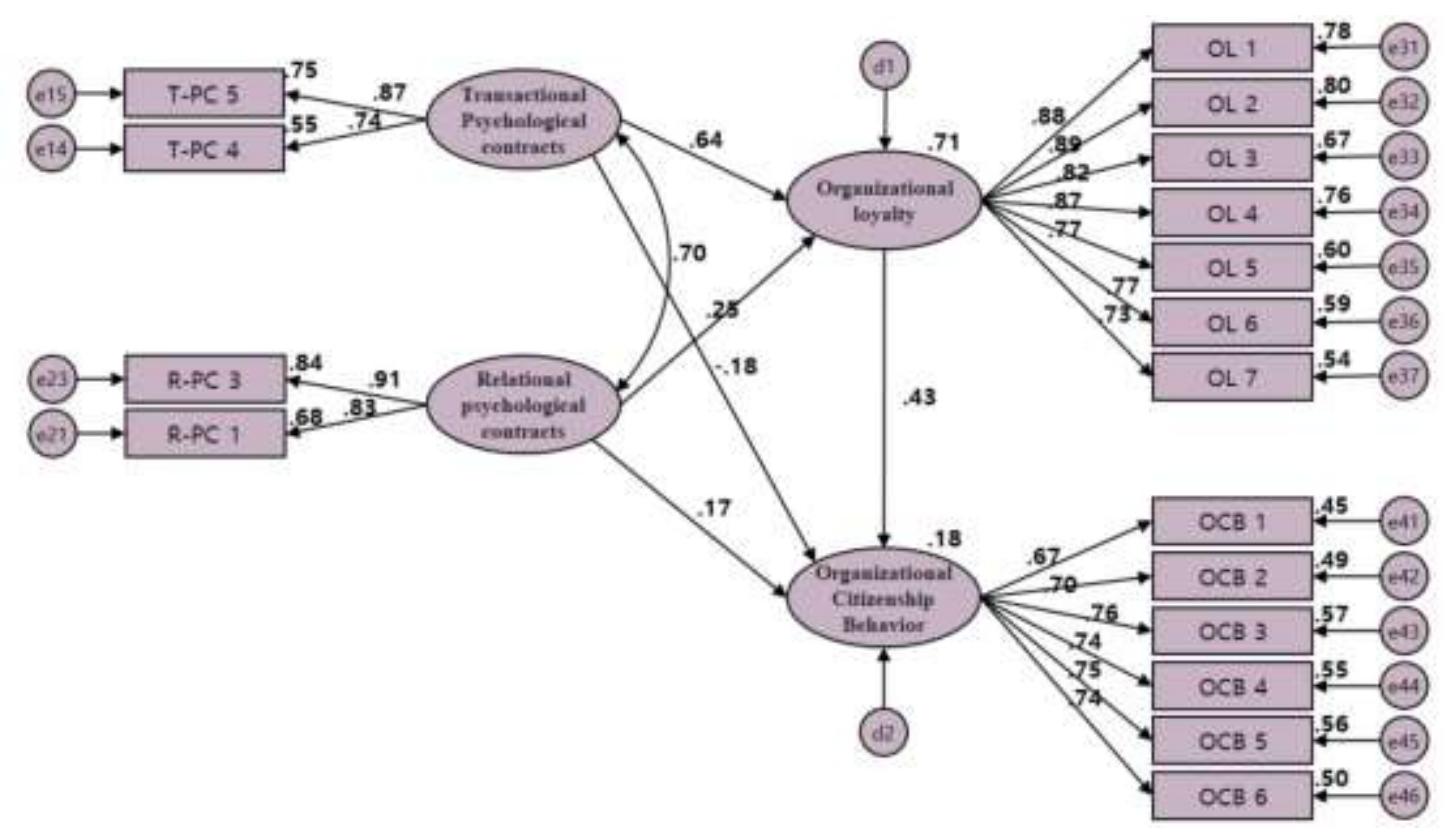

Figure 3 Structural Equation Modeling

Table 6 shows the results of analyzing the research model according to the results of the structural equation model. The hypothesis was adopted that the perception of compliance with transactional psychological contracts and relational psychological contracts will have a positive impact on organizational loyalty. The hypothesis that it would affect organized citizenship behavior was rejected. The hypothesis was adopted that organizational loyalty would affect OCB.

Table 6 Research model analysis

\begin{tabular}{|c|c|c|c|c|c|c|}
\hline \multicolumn{2}{|l|}{ Model } & B & $\beta$ & C.R. & $\mathrm{P}$ & result \\
\hline \multicolumn{2}{|c|}{$\begin{array}{l}\text { Transactional psychological contract } \\
\quad \rightarrow \text { Organizational loyalty }\end{array}$} & 643 & .791 & 6.514 & *** & adoption \\
\hline \multicolumn{2}{|c|}{$\begin{array}{l}\text { Relational psychological contracts } \\
\rightarrow \text { Organizational loyalty }\end{array}$} & .254 & 226 & 2.939 & .003 & adoption \\
\hline \multicolumn{2}{|c|}{$\begin{array}{l}\text { Transactional psychological contract } \\
\rightarrow \text { Organizational citizenship behavior }\end{array}$} & -.181 & -.112 & -1.038 & .299 & rejection \\
\hline \multicolumn{2}{|c|}{$\begin{array}{l}\text { Relational psychological contracts } \\
\quad \rightarrow \text { Organizational citizenship behavior }\end{array}$} & 168 & .075 & 1.406 & .160 & rejection \\
\hline \multicolumn{2}{|c|}{$\begin{array}{l}\text { Organizational loyalty } \\
\quad \rightarrow \text { Organizational citizenship behavior }\end{array}$} & .432 & 217 & 2.668 & .008 & adoption \\
\hline model fit & $\begin{array}{l}\text { CMIN=296.433, } \mathrm{df}=11 \\
\mathrm{RMR}=.056, \mathrm{GFI}=.860, \\
\mathrm{IFI}=.926, \mathrm{TLI}=.910, \mathrm{CF}\end{array}$ & $\begin{array}{l}000, \mathrm{C} \\
.811 \\
5, \mathrm{RMS}\end{array}$ & $\begin{array}{l}F=2.6 \\
86\end{array}$ & & & \\
\hline
\end{tabular}

\subsubsection{Mediating effect analysis}

Organizational loyalty was found to mediate the influence of perceptions of observance of transactional psychological contracts and observance of relational psychological contracts on OCB.

The hypothesis of direct effect (H2-1, H2-2) was found to be insignificant, so organizational loyalty was confirmed to have a completely mediated effect.

As for the magnitude of the impact on organizational loyalty, it was found that the transactional psychological contract was larger. 
Table 7 Mediating effect analysis (organizational loyalty)

\begin{tabular}{l|l|l|l|l}
\hline \multirow{2}{*}{ Dependent variable } & \multirow{2}{*}{ Independent variable } & \multicolumn{2}{l|}{ Mediating effect } & \multirow{2}{*}{ result } \\
\cline { 3 - 5 } Organizational loyalty & & $\mathrm{B}$ & $\mathrm{P}$ & \\
\cline { 2 - 5 } & Transactional psychological contract & .278 & .011 & adoption \\
\cline { 2 - 5 } & Relational psychological contracts & .110 & .013 & adoption \\
\hline
\end{tabular}

\section{Conclusion}

This study is meaningful in that it has re-tested the generally verified research results only for workers in SMEs. It was confirmed that the perception of compliance with psychological contracts influenced the OCB of SMEs workers through mediation of organizational loyalty. In addition, it was found that the effect of the transactional psychological contracts was greater than that of the relational psychological contracts.

This study is meaningful in that it provided contents necessary for organizational management for SMEs representatives, HR staff, and SMEs HR consultants.

However, this study has limitations in that the division of SMEs is considered as the whole, not as individual factors that differ in characteristics from each other and the OCB as a dependent variable. In order to conduct a more meaningful study, it is necessary to clarify the definition of SMEs according to the research purpose, and to classify and test the influencing factors by sub-factors of OCB.

\section{Acknowledgment}

This research was financially supported by Hansung University.

\section{References}

[1] Banerjee Minali;Singh Manju. Is Higher Education A Potential Means of Promoting Labour Mobility?. International Journal of Emerging Multidisciplinary Research. 2018; 2(1):27-31. DOI: 10.22662/IJEMR.2018.2.1.027

[2] Shweta Taluka; Dr. Suhasini Verma. Emerging Dimension of Board Gender Diversity in Corporate Governance- An Analysis. International Journal of Emerging Multidisciplinary Research. 2018;2(2):15. DOI: 10.22662/IJEMR.2018.2.2.001

[3] Rousseau, D. M. Psychological and Implied Contracts in Organizations. Employee Responsibilities and Rights Journal 2. 1989:121-39. DOI:10.1007/bf01384942

[4] Schein, E. H. Organizational Psychology 3rd ed. Englewood cliffs. NJ: Prentice-Hall Inc.; 1980.

[5] Jung, Y. G. Moderator Effects of Public Service Motivation on the Relation between Psychological Contract Form and Performance of In-Role and Extra-Role Behaviors. Journal of Korean Public Police and Security Studies. 2010;7(2):1-23. DOI:10.25023/kapsa.7.2.201008.1

[6] Kim, H. K., Wang, J. S. The Effect of Servant Leadership on Organizational Citizenship Behavior. The Journal of Humanities and Social science. 2018;9(2):1073-86. DOI:10.22143/hss21.9.2.85

[7] Organ, D. W. Organizational citizenship behavior: The good soldier syndrome. Lexington MA: Lexington Books; 1988.

[8] Chung, H. J., Lee, D. M. The Effect of Psychological Contract on Organizational Citizenship Behavior: Mediating Effect of Positive Psychological Capital. Journal of Organization and Management. 2018;33(3):291-309. DOI:10.23839/kabe.2018.33.3.291

[9] Podsakoff, N. P., Whiting, S. W., Podsakoff, P. M. \& Blume, B. D. Individual and organizational-level consequences of organizational citizenship behaviors: A meta-analysis. Journal of Applied Psychology. 2009;94(1):122-41. DOI:10.1037/a0013079

[10] Restubog, S. L. D., Bordia, P. \& Bordia, S. The interactive effects of procedural justice and equity sensitivity in predicting responses to psychological contract breach: An interactionist perspective. Journal of Business and Psychology. 2009;24:165-78. DOI:10.1007/s10869-009-9097-1.

[11] William, H. Turnley \& Daniel, C. Feldman. The impact of psychological contract violations on exit, voice, loyalty and neglect. Human Relations. 1999;52(7):895-922. DOI:10.1177/001872679905200703

[12] Robinson, S. L. \& Morrison, E. W. Psychological contracts and OCB: The effect of unfulfilled obligations on civic virtue behavior. Journal of Organizational Behavior. 1995;16(3):289-98. DOI:10.1002/job.4030160309.

[13] Robinson, S. L. \& Rousseau, D. M. Violating the Psychological Contract: Not the Exception but the 
Norm. Journal of Organizational Behavior. 1994;15:245-259. DOI:10.1002/job.4030150306

[14] Turnley, W. H. \& Feldman, D. C. The impact of psychological contract violations on exit, voice, loyalty and neglect. Human Relations. 1999;52:895-922. DOI:10.1177/001872679905200703

[15] Kaur Mahal, Prabhjot. HR Practices as Determinants of Organizational Commitment and Employee Retention. The IUP Journal of Management Research. 2012;11(4):37-53. Available at SSRN: https://ssrn.com/abstract $=2184208$

[16] Shekhar, Nandini \& Kumar, D.N.S. Perspectives Envisaging Employee Loyalty : A Case Analysis. SSRN Electronic Journal. 2011. DOI:10.2139/ssrn.1961430 